Bioscientia Medicina: Journal of Biomedicine \& Translational Research

Journal Homepage: www.bioscmed.com

\title{
Effects of Oral Administration of Monosodium Glutamate (MSG) on Obesity in Male Wistar Rats (Rattus Norvegicus)
}

\section{Mulyati Sri Rahayu ${ }^{*}$, Sri Wahyuni², Yuziani ${ }^{3}$}

${ }^{1}$ Department of Anatomical Pathology, Faculty of Medicine, Universitas Malikussaleh, Aceh, Indonesia ${ }^{2}$ Department of Biochemistry, Faculty of Medicine, Universitas Malikussaleh, Aceh, Indonesia

${ }^{3}$ Department of Pharmacology, Faculty of Medicine, Universitas Malikussaleh, Aceh, Indonesia

\section{A R T I C L E I N F O}

Keywords:

Monosodium glutamate

Obesity

Lee index

Wistar rats

\section{*Corresponding author:}

Mulyati Sri Rahayu

\section{E-mail address: \\ mulyati.srirahayu@unimal.ac.id}

All authors have reviewed and approved the final version of the manuscript.

\begin{abstract}
A B S T R A C T
Background: Monosodium glutamate (MSG) is one of the most widely employed food enhancers. Although the umami compound, controversy persists regarding the effects of MSG intake on body weight. Chronic MSG intake may result in excessive body weight gain and obesity. Consumption of MSG result in organ damage, cardiovascular disease, oxidative stress, and also risk factors for obesity. This study aims to determine the effect of oral MSG on obesity in adult male Wistar rats (Rattus norvegicus). Methods: This true experimental study used the post-test control group design. Twenty-four adult male Wistar rats were randomly divided into four groups: control (received distilled water), Group 1 (MSG $0.378 \mathrm{mg} / \mathrm{gr}$ BW), Group 2 (0.756 mg/gr BW) and Group 3 (1.512 mg/gr BW). The obesity parameter was obtained by the Lee index. Kruskal-Wallis test follows by Mann-Whitney test were used to compare the Lee index between groups. Results: Lee's index mean for each group was $358.4 \%, 314.1 \%$, $287.8 \%$, and $320.9 \%$, respectively. The Kruskal Wallis test showed a significant difference in the Lee index between groups $(p=0.043)$. A follow-up test using MannWhitney found a significant difference between group 2 and the control group ( $p=$ $0.043, \mathrm{p}<0.05)$. The mean of Lee index of group 2 was $70.51 \%$ lower than the control group. Conclusion: This study concluded that Lee index was not increased in MSGtreated rats than in the control group after oral MSG intervention for 21 days.
\end{abstract}

https://doi.org/10.32539/bsm.v5i9.355

\section{Introduction}

Monosodium glutamate (MSG) is a flavour enhancer that increases sweetness and saltiness and reduces sour and bitter tastes in food products.1 L-glutamate binds to receptors in the taste buds and stimulates the distinctive umami taste provided by MSG. The use of Monosodium Glutamate (MSG) in food is increasing due to fast food popularity. The Food and Agriculture Organization (FAO) and the World Health Organization (WHO) stated that MSG as a food flavour enhancer with an acceptable daily intake (ADI) is $0-120 \mathrm{mg} / \mathrm{kg}^{1,2}$.

Excessive and continuous MSG consumption increases the activity of a-ketoglutarate, nitric oxide synthase, and protein kinase $\mathrm{C}$, causing increased lipid peroxidation. This condition leads to an increase in the risk of obesity ${ }^{3}$.

Administration of MSG to neonatal rats causes damage to the ventromedial hypothalamic nucleus and arcuate nucleus, leading to obesity due to impaired energy metabolism ${ }^{4}$ and decreased sympathetic and thermogenic activity of brown adipose tissue / BAT5. Besides, there is also damage to the cholinergic infundibular system in the hypothalamus. The hypoactivity of this system causes the accumulation of choline resulting in metabolic disorders, namely an 
increase in phospholipid synthesis/transport in obese mice 6 .

The role of MSG, as a food additive, in the global obesity epidemic is still unclear. This study aims to investigate the effect of oral MSG on obesity in male Wistar rats (Rattus norvegicus).

\section{Methods}

This true experimental laboratory study used the Post-test control group design. Twenty-four adults male Wistar rats were randomly divided into four groups, and the experimental group were supplemented with MSG. MSG doses used in this research were acceptable daily intake (ADI) doses that WHO / FDA has approved (60 mg/kg BW) and converted into doses of experimental animals. The control group were received distilled water. Group 1, 2, and 3 were administered oral MSG solution at 0.378 $\mathrm{mg} / \mathrm{gr} \mathrm{BW} ; 0.756 \mathrm{mg} / \mathrm{gr} \mathrm{BW}$ and $1.512 \mathrm{mg} / \mathrm{gr} \mathrm{BW}$, respectively, on a daily basis for twenty-one days. After this period, the animals were sacrificed. The animal protocol was approved by the Research Ethics Committee of the Faculty of Medicine of Syiah Kuala University.

The obesity parameter was estimated according to the Lee index for each animal. This index consists of dividing the cubicle root of the weight in grams by the naso-anal length in millimetres multiplied by 1000 . With normal body composition in rats, the Lee index is 295 to 310 , a value of $\square 300$ was classified as normal. Rats with values $>300$ were classified as obese. Lee et al. explained that calculating the obesity index in experimental animals such as mice was carried out using several methods, including the Rõhrer index, Lee index, and TM index ${ }^{7}$.

Data were analyzed with computer software and presented as the mean \pm standard deviation (SD) for Lee Index (LI). Kruskal-Wallis test follows by Mann-Whitney test were used to compare the variables between groups. The difference between groups was defined as statistically significant when a p-value $<0.05$.

\section{Results}

The control group had the highest Lee index score, while the lowest mean of Lee Index was found in group 2. The Kruskal-Wallis test showed a difference in the mean Lee index between groups. The follow-up test results of the Mann-Whitney test showed a significant difference in the Lee index between the control group and group $2(\mathrm{p}=0.043)$; the mean Lee index score in group 2 was 70.51 lower than the control group. Lee Index (LI) for each group shown in Table 1.

Table 1. Lee index difference in Control and Experimental Groups

\begin{tabular}{|c|c|c|c|c|c|c|}
\hline \multirow{5}{*}{$\begin{array}{l}\text { Lee's } \\
\text { Index } \\
\text { (g/cm) }\end{array}$} & Group & Median & Minimum & Maximum & Mean \pm Sd & $\boldsymbol{P}$ \\
\hline & Control & 390.18 & 298.81 & 406.27 & $358.40 \pm 43.84$ & \multirow[t]{4}{*}{$0.043^{*}$} \\
\hline & Group 1 & 320.77 & 261.18 & 360.56 & $314.19 \pm 37.31$ & \\
\hline & Group 2 & 289.50 & 272.31 & 300.00 & $287.89 \pm 10.74$ & \\
\hline & Group 3 & 322.93 & 322.31 & 370.03 & $320.97 \pm 41.97$ & \\
\hline
\end{tabular}

*Kruskall-Wallis test. Values are statistically significant at $\mathrm{p}<0.05 . \mathrm{SD}=$ standard deviation, $\mathrm{n}=6$.

\section{Discussion}

Our study showed that the mean value of Lee's index of the treatment group was lower than the control group. These results are in line with research conducted by Kondoh and Torii; the experiment group that was giving $1 \%$ MSG (1.1\% MSG monohydrate, $60 \mathrm{mM}$ in water; $0.029 \mathrm{kcal} / \mathrm{g}$ solution; Ajinomoto, Tokyo, Japan) for six weeks had a mean value of body weight that was lower than the control group ${ }^{8}$. Meanwhile, Nakamura reported a higher mean body weight of mice in the control group $(33.5 \pm 2.0)$ than the treatment group after being administered MSG 0.064\% (32.9 \pm 1.5$)^{9}$. Dolnikoff found that subcutaneous injection of MSG 4g / kg BW for 30 days in neonatal rats showed a lower mean body weight $(72.9 \pm 1.5)$ than the control group $(95.8 \pm 1.6)^{10}$.

Several studies showed an increase in the body weight of mice. Sasaki proved that there was a significant increase in body weight $(66.3 \pm 1.2)$ with subcutaneous administration of $4 \mathrm{mg} / \mathrm{g}$ BW MSG for 54 weeks $(\mathrm{p}<0.01)^{4}$. A study of administering MSG orally for 32 weeks in neonatal mice showed no effect on 
increasing body weight, abdominal fat weight (epididymis, mesenteric, perirenal), and leptin levels in the body. Consumption of MSG also does not cause fat accumulation 9 .

Reports on the effect of MSG consumption on body weight vary widely, with some studies showing an increase in body weight 11,13 , while other studies have shown a decrease in body weight ${ }^{8}$ or no effect on body weight ${ }^{14}$. It is important to note that each study has a different administration route, MSG doses, and animal study age.

Direct exposure to high doses of glutamate or MSG causes cell death due to excitotoxicity, whereas direct injection of high doses of newborn mice causes neuron cell death in the hypothalamus, leading to obesity. Most oral glutamate will be metabolized through the first pass, for example, in the digestive organs (gut). Therefore the metabolism of MSG or glutamate depends on the route of administration ${ }^{9}$. This study used a low oral treatment dose which is the approximate average dose consumed by the human. This result is very different from the previous study by Olney et al. in mice given MSG injection of $4 \mathrm{~g} / \mathrm{kg}$ body weight during pregnancy. This study reported that MSG administration led to obesity, neuroendocrine disorders, behavioural disorders, and brain damage to neonatal mice ${ }^{15}$.

L-glutamate receptors may also mediate the effect of MSG on body weight in the gastrointestinal (mouth or intestinal) associated with afferent fibres from the vagus nerve ${ }^{16}$. Glutamate receptors are associated with innervation in the mouth (associated with taste receptors and sensory nerves) and upper and lower gastrointestinal tract (associated with vagus afferents in the stomach) ${ }^{8}$. Monosodium glutamate stimulates oral glutamate receptors and produces an umami taste. MSG stimulation of umami taste increases the efferent activity of the pancreatic vagal nerve and stimulates insulin secretion. Furthermore, stimulation of the MSG solution on the mouth and intestinal receptors will increase the stomach's vagus nerve's efferent branch activity ${ }^{17}$.

According to Onaolapo, administering oral MSG will deliver the initial dose of MSG into the gastrointestinal lumen, indirectly activating vagal afferents (from the gastric, celiac, and hepatic branches) by produce and release of $\mathrm{NO}$ and $\operatorname{serotonin}^{8,16}$. Such activation affects adipocyte fat metabolism mediated by autonomic innervation and the function of the gastrointestinal tract itself (e.g. MSG is known to induce gastric emptying after consuming a high protein $\operatorname{diet}^{17}$. This hypothesis needs further investigation.

\section{Conclusion}

This research concluded that the Lee index did not increase in MSG-treated rats compared to the control group after oral monosodium glutamate intervention for 21 days.

\section{References}

1. James O, Yetunde A. Acute Low Dose Monosodium Glutamate Retards Novelty Induced Behaviours in Male Swiss Albino Mice. J Neurosci Behav Heal 2011;3(4),51-6.

2. Kurtanty D, Faqih DM, Upa NP. Review Monosodium Glutamat.( 4th ed). Sukmawijaya AP (editor). Jakarta: Primer Koperasi Ikatan Dokter Indonesia;2018.

3. Onyema OO, Farombi EO, Emerole GO, Ukoha AI, Onyeze GO. Effect of Vitamin E on monosodium glutamatinduced hepatoxicity and oxidative stress in rats. Indian J. Biochem. Biophys 2006; 43:20-4.

4. Sasaki Y, Suzuki W, Shimada T, Iizuka S, Nakamura S, Nagata M. Dose dependent development of diabetes mellitus and nonalcoholic steatohepatitis in monosodium glutamate-induced obese mice. Life Sci 2009; 85, 490-498.

5. Gomathi, N, Malarvili T, Mahesh R, Begum VH. Lipids lowering effect of Hibiscus RosaSinensis flower petals on monosodium glutamate (MSG) induced obese rats. Pharmacologyonline 2008; 1, 400-409.

6. Matysková R, Maletínská L, Maixnerová J, Pirnik Z, Kiss A, Zelezna, B. Comparison of the obesity phenotypes related to monosodium glutamate effect on arcuate nucleus and/or the 
high fat diet feeding in C57BL/6 and NMRI mice. PhysiolRes 2008;57,727-734.

7. Lee S-II, Kim JW, Lee YK, Yang SH, Lee I, Suh JW, Kim SD. Anti-obesity Effect of Monascus pilosus Mycelial Extract in HighFat Dietinduced Obese Rat.Journal Applied Biomolecular Chemistery 2011;54, 197-205.

8. Kondoh T, Torii K. MSG intake suppresses weight gain, fat deposition, and plasma leptin levels in male Sprague-Dawley rats. Physiology \& Behavior 2008;95,135-144.

9. Nakamura H, Kawamata Y, Kuwahara T, Smriga M, Sakai R. Long-Term Ingestion of Monosodium L-Glutamate Did Not Induce Obesity, Dyslipidemia or Insulin Resistance: A Two-Generation Study in Mice. J Nutr Sci Vitaminol 2013; 59,129-135.

10. Dolnikoff M, Hidalgo AM, Machado UF, Lima FB, Herrera E. Decreased lipolysis and enhanced glycerol and glucose utilization by adipose tissue prior to development of obesity in monosodium glutamate (MSG) treated-rats. Int J Obes Relat Metab Disord 2001; 25(3): 426-433.

11. Hermanussen M, Garcia AP, Sunder M, Voigt M, Salazar V, Tresguerres TA. Obesity, voracity, and short stature: the impact of glutamate on the regulation of appetite. Europ $\mathrm{J}$ of Clin Nutr 2006; 60:25-31

12. Nagata M, Suzuki W, Iizuka S, Tabuchi $M$, Maruyama H, Takeda S. Type 2 Diabetes Mellitus in Obese Mouse Model Induced by Monosodium Glutamate. Exp Anim 2006; 55(2):109-115.

13. Kim YW, Choi DW, Park YH., Huh JY, Won KC, Choi KH. Leptin-like effects of MTII are augmented in MSG-obese rats. Regul Peptides 2005;27:63-70.

14. Tordoff MG, Aleman TR, Murphy MC.(2012). No effects of monosodium glutamate consumption on the body weight or composition of adult rats and mice.Physiol Behav 2012;107(3):338-45.

15. Olney JW. Brain lesions, obesity, and other disturbances in mice treated with monosodium glutamate. Science 1969;164(3880):719-21.

16. Onaolapo OJ, Onaolapo AY, Akanmu MA, Gbola O. Evidence of Alterations in Brain Structure and Antioxidant Status Following LowDose Monosodium Glutamate Ingestion. Pathophysiology 2016;23(3):147-56

17. Niijima A. Basic Characteristic of Glutamate and Umami Sensing in the Oral Cavity and Gut: Reflex of Oral, Gastrointestinal and Hepatoportal Glutamate Sensors on Vagal Nerve Activity. J Nutr 2000; 130: 971-3. 